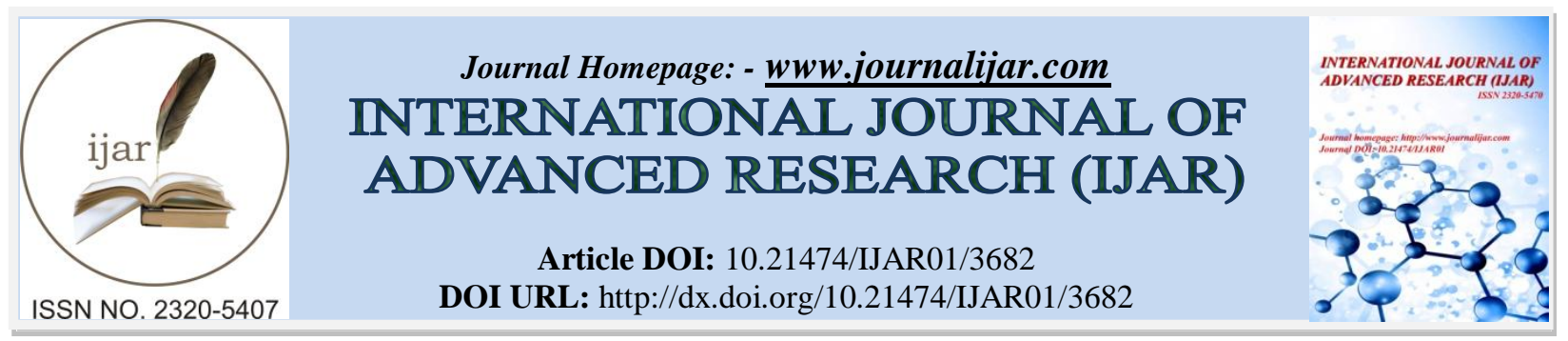

RESEARCH ARTICLE

\title{
A STUDY OF ERRORS AND MISCONCEPTIONS IN SCIENCE IN RELATION TO SCIENTIFIC ATTITUDE AMONG SECONDARY SCHOOL STUDENTS.
}

Dr. Manmeet Baweja (Oberoi).

Principal cum Professor, Shah Satnam Ji College of Education, Sirsa.

\section{Manuscript Info}

Manuscript History

Received: 12 January 2017

Final Accepted: 08 February 2017

Published: March 2017

Key words:-

Errors, Misconceptions, Scientific

Attitude,Concept Achievement Test.

\begin{abstract}
To promote effective and meaningful learning there is need to identify misconceptions as prevalence of misconceptions among students not only presents an obstacle to learning but also interferes in further learning. A descriptive study was conducted on a sample of 912 students studying in ninth class in various schools of Punjab. For the study Concept Achievement Test in Science was constructed and standardized and was administered to identify errors and misconceptions among students. Scientific Attitude Scale (SAS) developed and standardized by Gakhar and Kaur (1995) was used for measuring the attitude relevant in science education. The results related to patterns of errors indicate that secondary school students with unfavourable scientific attitude committed more errors as compared to their counterparts with favourable scientific attitude. The suggestions for educational implications are also discussed.
\end{abstract}

Copy Right, IJAR, 2017,. All rights reserved.

\section{Introduction:-}

Attitude has been identified as an important correlated towards achievement of students. Chen, Hui-Ling (2001); and Mehra (2004) found mathematics attitude to be related to achievement while findings of studies by Bandopadhyaya (1984); Paul (1986); Kar(1990); and Nelliappan (1992); showed significant relationship between scores on scientific attitude and achievement in science. On the other hand Many researches were done in various subjects to identify the naïve ideas (misconceptions) of students that can create learning difficulties for students and ultimately causing low achievement (Arnaudin and Mintzes, 1985; Boyes and Stainstreet, 1991; Driver, 1993; Marques and Thompson, 1997; Palmer, 1998). Researches were conducted to identify misconceptions of various concepts of science by Eryilmaz and Surmeli(2002), Cetin(2004),Haki(2005) and Kutuluay(2005) who revealed that errors among secondary school students were due to mistakes, lack of knowledge and misconceptions. While identifying errors and misconceptions among students they referred mistakes as the incorrect answers given by the students who have correct scientific conceptions while lack of knowledge as the incorrect answers given by the students who have incorrect scientific conceptions and have no confidence for their wrong conceptions, in case the students have confidence for their wrong conceptions, these were referred as misconceptions. There are a lot of researches in the area of science achievement but there is paucity of researches in the area "errors and misconceptions in learning of scientific concepts" in Indian context. So the present study is an endeavor in this direction to provide empirical evidence with regard to problems in learning of scientific concepts with objectivity and scientifically. 


\section{Objectives:-}

- To find out the level of performance of secondary school students on Concept Achievement Test (CAT) in science in relation to scientific attitude.

- To find out the percentage of secondary school students who committed errors and misconceptions on Concept Achievement Test (CAT) in science in relation to scientific attitude.

- To study the patterns of errors and misconceptions on Concept Achievement Test (CAT) in science in relation to scientific attitude.

\section{Hypothesis:-}

The students with favourable scientific attitude will differ from students with unfavourable scientific attitude in their pattern of errors and misconceptions on Concept Achievement Test (CAT) in science.

\section{Method:-}

A descriptive method of research was used in the conduct of the study. The study was completed in two phases:

Phase 1: Construction and standardization of Concept Achievement Test (CAT) in science by the researcher for the identification of errors and misconceptions to include the concepts of adaptations, habitat, biosphere, ecosystem, food chain and food web, functions of ecosystem, biomass and biodiversity from the PSEB prescribed science text book of ninth class.

\section{Phase II: Field Work}

The preliminary draft of the test contained fifty three test items to be responded on three tiers. This draft was administered to 220 students of ninth class from various schools in Patiala. On the basis of the indices of the item difficulty and in the view of the experts 23 items were discarded and 30 items were selected. Then that test was administered to 125 secondary school students of Patiala to find out the reliability and validity of the test. First tier included multiple choice items having one right answer and three distracters. The second tier required students to write reason for the response. Third tier asked students about their confidence for the answer in first two tiers. Total achievement score of each student was calculated according to the students' multiple choice item scores, reasoning part scores and the confidence level scores together.

\section{Sample:-}

A sample of 912 students of $9^{\text {th }}$ class studying in high and senior secondary government schools was selected randomly selecting 33 schools from seven districts of Punjab namely, Patiala, Ropar, Ludhiana, Bathinda, Mansa, Fatehgarh Sahib and Sangrur.

\section{Tools:-}

\section{Following tools of research were used for the collection of data:-}

1. Concept Achievement Test constructed and standardized by researcher herself.

2. Scientific Attitude Scale (SAS) developed and standardized by Gakhar and Kaur (1995) was used for measuring the attitude relevant in science education.

\section{Findings:-}

The major findings of the study are summarized below:The achievement of secondary school students of Punjab on Concept Achievement Test (CAT) in science was moderate.

- The secondary school students with favourable scientific attitude performed significantly higher than their counterparts with unfavourable scientific attitude on Concept Achievement Test (CAT) in science. The level of performance on Concept Achievement Test (CAT) in science was directly/positively affected by achievement and attitude. The secondary school students with unfavourable scientific attitude committed more errors in the concept areas of 'adaptations', 'habitat', 'food chain and food web', 'functions of ecosystem' and 'biomass and biodiversity'.

- The secondary school students with unfavourable scientific attitude significantly have more objectively false conceptions as compared to their counterparts with favourable scientific attitude on Concept Achievement Test (CAT) in science.

- There is no significant difference in the mean misconceptions of secondary school students with favourable and unfavourable scientific attitude on Concept Achievement Test (CAT) in science. 
- It is found that students with unfavourable scientific attitude have significantly more mean mistakes, lack of knowledge and misconceptions as the sources of errors as compared to their counterparts on Concept Achievement Test (CAT) in science.

\section{Testing of Hypothesis:-}

The hypothesis formulated was accepted. The results related to patterns of errors indicate that secondary school students with unfavourable scientific attitude committed more errors as compared to their counterparts with favourable scientific attitude.

\section{Educational Implications:-}

In the light of the findings of the present study regarding errors and misconceptions in science learning among secondary school students, following implications emerged that can be used by teachers to improve the delivery of science education.

1. The findings of this study could facilitate teachers in their planning and implementation of relevant measures to reduce the incidence of students' misunderstandings about the concept of environment. A teacher should focus on students cognitive level to eliminate misconceptions, because most of the students in high schools and all students in elementary and junior high schools are in concrete levels; therefore, the major focus of instruction for those students should link between concept and concrete experiences and expect difficulties on linking concrete experiences to abstract concepts because any science concept has a relationship with other concepts, so students have to link the ideas and other concepts.

2. The teacher plays a pivotal role in identifying, reconstructing and internalizing the scientific knowledge among the students. The teacher should encourage students to test their conceptual frameworks in discussion with other students and by thinking about the evidence and possible tests. He should revisit common misconceptions as often as he/she can. He should allow students to have sufficient experience of the first concept before introducing he next one.

3. Teachers should involve use of animations, videos, activities and alternative methods of teaching viz. concept mapping (representing knowledge in graphs), clustering (finding groups for data), mental modeling (asking open ended questions), problem solving and laboratory skills.

4. The results of the study showed that students made errors, due to mistakes, lack of knowledge or due to misconceptions. These misconceptions resist changing and obstructing the learning process. The teachers are required to take students misconceptions into account. The more the teachers know about their students' misconceptions the more guidance they will be able to provide them to learn. This could contribute to the professional development of science teachers. Smith and Anderson (1993) and Lawrenz (1986) advocated that during (preservice and in-service) teacher education programmes the teachers should be given chances to identify misconceptions held by the pupils in their classrooms.

5. Identification of the students' misconceptions in science for the unit of environment by Concept Achievement Test (CAT) in science can give some feed back to the text book editors.

6. Students' misconceptions and alternative ideas can be taken into consideration by curriculum developers and remediation techniques of them should be designed. If these techniques can be combined with small group work with demonstration and appropriate hands-on activities, they should be very powerful methodology for science classrooms.

7. To remove misconceptions among students the teachers should provide more structured opportunities for students to talk about ideas at length, both in small groups and whole class discussions.

8. This work has identified new material which can be utilized by science educators both in the classroom and in teachers' pre-and in-service courses. This new material includes a number of misconceptions. These new pieces of information add to the overall picture of students' conceptual development and with this knowledge, educational practitioners will be in a better position to make necessary changes and improvements in their class room practices to enhance the student learning. 


\section{References:-}

1. Arnaudin, Mary V. and Mintez, Joel J. (1985). Student's alternative conceptions of the human circulatory system : a cross age study, Science Education, 69 (5), 721-33.

2. Bandopadhyaya, J. (1984). Environmental influence, academic achievement and scientific aptitude as determinants of adolescents attitude towards science stream, Ph.D. Psychology Calcutta University, In the Fourth Survey of Research in Education, Vol. I, 722.

3. Boyes, and Edward and Stanisstreet, Martin (1991). Misconceptions in first year undergraduate science students about energy sources for living organisms, Journal of Biological Education, 25(3), 209- 213.

4. Cetin, Gulcan; Stanisstreet, Martin (2004). Developing and implementing an instructional technology aided conceptual change approach in teaching ecology concepts in ninth grade, The Turkish Online Journal of Educational Technology, 3(1), 1303-6521.

5. Chen, Hui- Ling (2001). A study of different factor structures and different influences on mathematics achievement, Ph.D. Thesis, Panjab University Chandigarh.

6. Driver, R. (1993). Beyond appearances : the conservation of matter under physical and chemical transformations, In R. Driver, E. Guesene and A. Tiberghien (Eds.). Children's Ideas in Science, 145-169, London : Open University Press.

7. Eryilmaz, A and Surmeli, E. (2002). Identifying students' misconception on heat and temperature through three tier questions, Paper presented at the 5th National Conference on Science and Mathematics Education,

8. On line, http://www.fedu.metu.edu.tr/ufbmek-5/b_kitabi/pdf/fizik/bildiri/t110dd.pdf.

9. Haki, Pesman. (2005). Development of a three tier test to assess ninth grade students' misconceptions about simple electric circuits, M.Sc. Thesis, Middle East Technical University.

10. Kar, D.K. (1990). A study of relationship between attitude towards and achievement in general science of class IX students of Cuttak city, In Fifth Survey of Educational Research, Vol. II, New Delhi: NCERT, 145-46.

11. Kutluay, Y. (2005). Diagnostics of eleventh grade students' misconceptions about geometric optic by a three tier test, Master of Science, Department of secondary Science and Mathematics Education, Middle East Technical University.

12. Lawrenz, Frances (1986). Misconceptions of physical science concepts among elementary school teachers, School Science and Mathematics, 86, 654-660.

13. Marques, Luis; Thompson (1997). David Portuguese student's understanding at ages 10-11 and 14-15 of the origin and nature of the earth and the development of life, Research in Science and Technological Education, 15(1), 29-51.

14. Mehra, C. (2004). A study on the achievement at the secondary level and some of its determinants, Ph.D. Education, Burdwan University, Burdwan.

15. Nelliappan, N.O. (1992). A study of scientific attitude and interests among higher secondary biology students in relation to their learning environment, In Fifth Survey of Educational Research, Vol. II, New Delhi: NCERT, 1254.

16. Palmer, D.H. (1998). Measuring contextual error in the diagnosis of alternative conceptions in science, Issues in Educational Research, 8(1), 65-76.

17. Paul, S. (1986). A study of cognitive styles of high school students of home science in relation to age, achievement, home environment and social class, Ph.D. Education, Agra University.

18. Smith,E. and Anderson,C.W. ( 1993 ). Teaching strategies associated with conceptual change. Science Teaching, 30(2), 11-126.

19. Turkmen, H. and Usta E. (2007). The role of learning cycle approach overcoming misconceptions in science, Kostamonu Education Journal, 15(2), 491-500.

20. Tytler, R. (2002). Teaching for understanding insight: student conception research and changing view of learning, Australian Science Teachers Journal, 48(3), 14-21. 